\title{
IDENTIFYING THE CULTURE OF THE MUHAMMADIYAH ISLAMIC BOARDING SCHOOL
}

\author{
Ahmad Mardalis ${ }^{*}$, Mirzam Arqy Ahmadi ${ }^{2}$, Mahasri Shobahiya ${ }^{3}$, Minhayati Saleh ${ }^{4}$ \\ 1,2,3Universitas Muhammadiyah Surakarta, Surakarta, Indonesia \\ ${ }_{4}^{4}$ IIN Walisongo, Semarang, Indonesia \\ *ahmad.Mardalis@ums.ac.id
}

\begin{tabular}{l}
\hline Article Info \\
\hline Article history \\
Received April 30, 2021 \\
Revised July 19, 2021 \\
Accepted July 22, 2021 \\
\hline
\end{tabular}

Keywords: Organization culture; Organization Culture Assessment; Pesantren Culture

\begin{abstract}
This study aims to determine the organizational culture at the Muhammadiyah Islamic Boarding School. This research method includes qualitative research with the object of research is the Islamic Boarding School Modern Imam Syuhodo Sukoharjo. This study's collection method was obtained by seeking information from high-ranking informants and distributing questionnaires filled out by respondents at the Muhammadiyah Islamic Boarding School. Data collection techniques are carried out by interview, observation, and documentation supported by OCAl instruments. The results of the Leadership Research show that from the point of view of the leadership's assessment of the current dominant organizational culture, namely clan culture (40) and hierarchy (23). The data obtained shows that there is a significant difference between clan and hierarchy. The research results concluded that clan is the dominant culture for the current organizational culture and the dominant culture for the expected culture. At the same time, the hierarchy becomes the dominant culture in the second position. Then the organization needs a greater sense of kinship and better regulations to maintain organizational stability.
\end{abstract}

\section{INTRODUCTION}

Many companies or organizations are multiplying in this modern era. Companies that have been around for a long time or even newly established or under development companies aspire to improve quality continuously. As time goes by, competition between one company and another cannot be avoided, even not only by companies but also competition between organizations cannot be avoided. The things that become habits in the organization will become the organizational culture. Of course, the culture created by an organization is following the foundations and principles of the organization.

Carl and Robert (1989) said organizational culture is a basic assumption. The group discovered and developed as it learns to cope with its external and internal problems. Organizational culture can predict as a job satisfaction pump for all members of the organization. In addition, organizational culture is one factor that significantly affects the work patterns of organizational members. The better the culture and the easier it is to understand and implement by workers, the organizational culture becomes quite important (Usman, 2019). 
Companies with good credit will be very influential in encouraging their human resources to work more productively (Supariyanto, 2014). Identify necessary changes in a project system implementation, according to the characteristics of a specific culture, or also in the organizational culture of the organization, and that is it according to the system needs (Pedro \& Mateus, 2017).

Robbins and Timothy (2015) explain that organizational culture can be said to be effective and efficient if a company has the following seven characteristics: the organization has innovation and suitable risk-taking methods, the organization can pay attention to everything in detail, the organization has an orientation to the result, the organization has an orientation to human resources in the organization, the organization has a team orientation that had been creating the organization has aggressiveness, and finally, the organization has stability. The cultural subsystem of representations generally includes a set of representations, ideologies, and beliefs shared by the members of a social group (Michel, 1996). After that progressive research effort increased the understanding of management the organizational culture, it will be challenging both the organizational theory and the strategic management theories as to the concept of an organizational culture propagated more human (Ivana, 2016).

Moeheriono (2012), Amia et al. (2013), Edison (2017), and Nelfianti et al. (2018) reveal that the factors of organizational culture are as follows: leadership, effectiveness, and efficiency at work, awareness, and a sense of independence from each member, and the process of forming the organizational culture itself. These things will influence the organizational culture that exists in an organization or company. Organizational culture is usually spearheaded by people who act as leaders, while leadership is the ability to persuade a group or individual to jointly achieve the goals or vision of the organization (Adi, 2013; Wartini, 2014).

The community is currently looking at Pesantren education, and not a few have registered their children or siblings to attend the pesantren. According to Zuhriy (2011), pesantren is an area with a culture not owned by other regions. The main elements of traditional Islamic boarding schools are santri, kyai, mosques as the center of activities, and reading classical books. According to him, pesantren can be divided into three major types: pesantren that only study classical books written by scholars in the past, modern pesantren that teach previous books and general sciences like other pesantren, and traditional pesantren in the countryside. These institutions (pesantren) have played a significant role in imparting domestic education and empowering the local economy ( Fahmi and Neni, 2019). However, some pesantren concerns that some Islamic schools limit secular education and indoctrinate students with the militant, extreme and fundamental version of Islam (Melanie et al., 2020).

Mukhibat (2015) argues that the culture of pesantren to build a humanist religious life makes the main characteristic of Islam that develops in Indonesia full of universal values by 
utilizing culture in carrying out Islamic da'wah. It is what distinguishes the spread of religion in Indonesia from countries in the Middle East or elsewhere. Cultural life in pesantren is identical and thick with religious values; besides, the pesantren also has a system that makes all elements disciplined (Ruchaini, 2016). Furthermore, a values statement may provide a glimpse into organizational culture (Jerry, 2018).

OCAl (Organizational Culture Assessment Instrument) is an instrument developed by professors Quinn and Kim Cameron that; the instrument used to provide an assessment of the culture experienced by the company or organization today. Four cultures become the dominant culture in an organization: clan, adhocracy, market, and hierarchy. Of the four cultures, one of which will become a culture that is believed and felt by members of the organization, which is evidence of the state of the organization (Susilo, 2018). Cultural values were defined as guiding ideals, core principles, norms, and strong beliefs about desirable and undesirable in communities or groups (Teressa \& Dianna, 2018).

The clan culture perceived by members of the organization means that the organization has a kinship atmosphere. They are making it easier for members of the organization to create good relationships from one member to another. The organization considered giving excellent attention to all its human resources and prioritizing its members' morale and welfare.

Adhocratic culture means that the organization has dynamic movements, an entrepreneurial spirit, and good creativity. Some people are brave enough to take new steps, proof that organizations always want to grow and innovate. Organizational leaders are initiators and people who are willing to take risks. Almost all members of the organization have an innovative nature, and fellow organizations

Results-oriented market organization culture. The existing leadership has the ambition always to win the competition with its competitors. Usually, the organization's head has a hardworking character and has many achievements in his life journey. Organizational reputation is significant for organizations that have this culture-the success of this organization is measured by the size of the market share that the organization can control.

The last culture is a hierarchy which means a very formal and highly ordered culture. Every individual who lives in this organization works according to the current flow of procedures. This cultural leader is a person who can coordinate all parts and prioritize efficiency in work. Success, which is the primary goal of this culture, is if the organization can produce reliable output, timeliness in all respects, and low costs. A sense of security at work is a priority for leaders who have this culture.

From this background, several questions arise to perfect and know the purpose of this research. The question is: (1) What are the characteristics of organizational culture in the Modern Muhammadiyah Islamic Boarding School? (2) How are the differences in the current organizational culture and organizational culture desired by the leadership of the boarding school? (3) What characteristics of the Modern Muhammadiyah Islamic Boarding School 
distinguish it from other Islamic boarding schools?. Meanwhile, this study aims to determine the organizational culture at the Muhammadiyah Islamic Boarding School.

\section{METHODS}

This research method includes qualitative research with the object of research is the Islamic Boarding School Modern Imam Syuhodo Sukoharjo. The method consists of two phases, and the first phase is an in-depth interview, ethnographic observation, and data collection to understand the existing cultural content. The second phase uses qualitative data to create a questionnaire where the responses are encoded quantitatively.

\subsection{Data And Data Source}

Primary data is data obtained directly from the object through interviews, observation, and documentation. In this case, the writer will interview the director or representative of the Imam Syuhodo Islamic Boarding School to seek detailed information with audio as evidence of the interview. Secondary data is data obtained from author sources and existing scientific papers. Books, journals, and websites have links to research themes to support the primary data used.

The OCAl (Organizational Culture Assessment Instrument) by Cameron and Quinn (2006). This instrument consists of six main dimensions, namely dominant characteristics, leadership style, employee management, organizational adhesive, strategic emphasis, and success measures. Each of the main dimensions in OCAl has four alternative questions based on four types of culture. The assessment carried out using OCAl consists of two stages: assessing the culture that is currently developing (now culture), then assessing the desired culture (preferred culture). The form of the OCAl instrument is measured by dividing 100 points for the four questions in each of the main dimensions so that the total value of the four statements in each of the main dimensions is 100 points. The most significant value is given to the statement that best fits the actual cultural conditions in the company and to the statement that best fits the employee's perception of the desired culture.

The questions asked by the author were responded to by respondents to be filled in on a point scale using the OCAl instrument as many as 24 questions and had four-component questions ( $A, B, C$, and $D)$, with the following formula:

$$
\begin{aligned}
& 1 A+2 B+3 C+4 D=100 \\
& 2 A+2 B+2 C+2 D=100 \\
& 3 A+3 B+3 C+3 D=100 \\
& 4 A+4 B+4 C+4 D=100 \\
& 5 A+5 B+5 C+5 D=100 \\
& 6 A+6 B+6 C+6 D=100
\end{aligned}
$$




\section{RESULTS AND DISCUSSION}

\section{Pesantren Culture}

Observations on the application of organizational culture seen at the Imam Syuhodo Islamic Boarding School can detail three cultural elements based on written literature reviews, namely artifacts, values, and basic assumptions. At the level of visible cultural artifacts to the eye, however, it is often found that they cannot be understood. Some of the artifacts seen at the company are:

1. The Imam Syuhodo Islamic boarding school building, located in Polokarto, Sukoharjo Regency, has a relatively simple design. The color of the building, which is dominated by green and yellow, and several symbols of Muhammadiyah that are present in several places, illustrates that this pesantren is an Islamic boarding school with the basic Muhammadiyah. According to the results of interviews with the director of the pesantren, the male complex has an area of $11,000 \mathrm{~m}$, while the female complex is about 10,000 square meters.

2. The layout of the Imam Syuhodo Islamic boarding school is determined by the waqf received from the waqif, so that in development, it must adjust to the terrain and area that owned, in the first development, it is in the male complex used for dormitories, local madrasah tsanawiyah, and local high schools. At the same time, the complex is a princess after the construction. The complex built a female dormitory and a special Madrasah Tsanawiyah for girls.

3. The slogan possessed by the Imam Syuhodo Islamic boarding school is not a random slogan but a prayer that was expecting to be embedded in both the students and the people in the pesantren. Taqwa, achievement, and independence are the slogans of the Imam Syuhodo modern Islamic boarding school. Taqwa, it is hoped that all elements in the pesantren will have devotion to Allah SWT. Achievement, it is hoped that the students will have an achievement that is not inferior to public schools in general. Meanwhile, being independent is also essential for students and students to live in society after completing their studies at the pesantren.

Based on the results of the interview, several points were obtaining. There are lots of ceremonies or celebrations that this pesantren has usually held annually. For example, a ta'aruf sermon or introductory cult is always held at the beginning of the study period to introduce the pesantren to new and old students. At the end of the study period, an event called Akhirussanah was also held. Pesantren also conducts a grand study every year; the Muhamadiyah Student Association usually makes this event.

In terms of humanity, class XII has the opportunity to carry out Da'i Hijrah in the month of Ramadhan for ten days every year. The event was an initial step as a warm-up to train imu in preaching because it would be deployed directly to the community. 


\section{Value}

The values possessed by this pesantren cannot be separated from the values of Muhammadiyah, which based on Islam. The values applied at the Imam Syuhodo Islamic Boarding School are as follows. First, aqidah is straight, and this is what is expected by the leadership to be embedded in all of its students. It is anticipated that after graduating from the pesantren, the alumni will not leave the teachings and basics of Islam. Second, noble morals this is something that is emphasized enough by the leadership. According to him, morals are number one while science is number two. The leadership expects the students to have good morals before having the science taught. According to him, someone who is knowledgeable but has no character is a dangerous thing. Then, achieving achievement, the leadership expects the students to excel in all fields. The leadership wanted to erase the stigma circulating that students could only recite Al-Qur'an, so it decided to pump up their studies to compete with other students of the same level.

\section{Basic Assumptions}

The level of basic assumptions is the assumption used by all personnel in the organization in their activities and trying to answer the reasons for each person to do something in the organization. Organizational Principles, from an interview with the Imam Syuhodo Islamic boarding school director, he explained that there would be no new building construction if it still did not have money independently. The leadership and the advisory board refuse to build the building if they do not have sufficient funds. The purpose of this pesantren was not separating from the objectives of the overseeing organization. It is hoped that students who graduate from the pesantren will graduate in terms of aqidah, have exemplary achievements, and have good morals. The leadership hopes that its graduates can continue the struggle waged by previous Muhammadiyah figures and scholars. Hopefully, they will become da'i and da'iah and become cadres in Muhammadiyah.

\subsection{Modern Organizational Culture}

Based on the interview results, the leader conveyed the state of the organizational culture that was being experienced and occurred at the Imam Syuhodo Islamic boarding school. After synchronizing with the modern organizational culture, the following are the results: 1) Innovation, which makes it different from other pesantren is that for the junior high school level, the pesantren is under the department of religion, while for the high school level it is under the education office. Although sometimes it is constrained by the policy of the religious department because the basic Muhammadiyah is sometimes slightly different from the policy of the department of religion. 2) Paying attention to details, the leadership wants the students at the pesantren to excel and master, especially in interpretation. It is also based on the wishes of the founder and wagif of this pesantren. 3) Orientation to People, the leadership wants and 
emphasizes that teachers and anyone who plays a role in the pesantren are Muhammadiyah activists. Every pesantren member is encouraged to be active in Muhammadiyah, at least in the branch where he lives. It is expected to prevent people from working without helping to spread preaching in Muhammadiyah and fighting for Muhammadiyah. 4) Team orientation, in forming a leadership team, always prioritizes Muhammadiyah cadres to become heads of sections or departments when running a program. According to him, fellow cadres can understand each other because they already have one vision and mission. 5) Aggressiveness, selecting teachers who already have much experience, especially being leaders in Muhammadiyah both in branches, and choosing those from Pondok graduates. Moreover, 6) Stability, in maintaining the stability of the pesantren, the leadership has divided all tasks according to their portion. The director cannot immediately decide to create a different system from the Pondok, which usually follows what the kyai said. It is necessary to hold deliberations with the daily leadership to determine a policy. The daily leadership consists of the director, deputy director, secretary, and treasurer.

Islamic Boarding School Cultural Assessment Using OCAI (Organizational Culture Assessment Instrument)

Based on the results of the questionnaires that had been distributing, it can be seen that the results of the assessment using the OCAl instrument are carried out based on a comparison between the leaders and non-leaders. The leadership will produce the results of the current cultural assessment and the expected culture. Likewise, with non-leaders, the results of current culture according to non-leadership and culture are expected to be studied in this discussion. Leadership Research Results The results showed that from the point of view of the leadership's assessment of the current dominant culture of the organization, namely the culture of the clan (40) and hierarchy (23). The data obtained shows that there is a significant difference between clans and hierarchies. The dominant cultural order according to leadership at this time is clan culture (40), hierarchy (23), adhocracy (19), and market (18). The cultural profile according to the leadership can be seen in the image below, which shows that there has been a shift for the two prominent cultures. Both are clans that shift to number (44) and hierarchy shift to number (25).

The clan culture is a culture that is usually dominant in pesantren, where the leaders and non-leaders have something in common, namely teaching the students. So that differences in the position do not affect the implementation of teaching and learning activities daily. The leadership creates a thick atmosphere with a sense of kinship, making this culture feel closer to one individual to another. The organization provides comfort to members and makes the organization a new family. In hierarchical culture, organizational conditions are governed by rules and procedures. It is what makes leaders feel that the rules that the organization owns 
are fundamental. However, if there are too many rules, it will only make the leader feel constrained, so that he will lose his sense of comfort in the organization.

Table 1. Cultural Leadership Results

\begin{tabular}{lll}
\hline Culture Type & Current Culture & Expected Culture \\
\hline CLAN & 40 & 44 \\
ADHOCRACY & 19 & 16 \\
MARKET & 18 & 15 \\
HIERARCHY & 23 & 25 \\
TOTAL & 100 & 100 \\
\hline
\end{tabular}

Source: Processed 2020

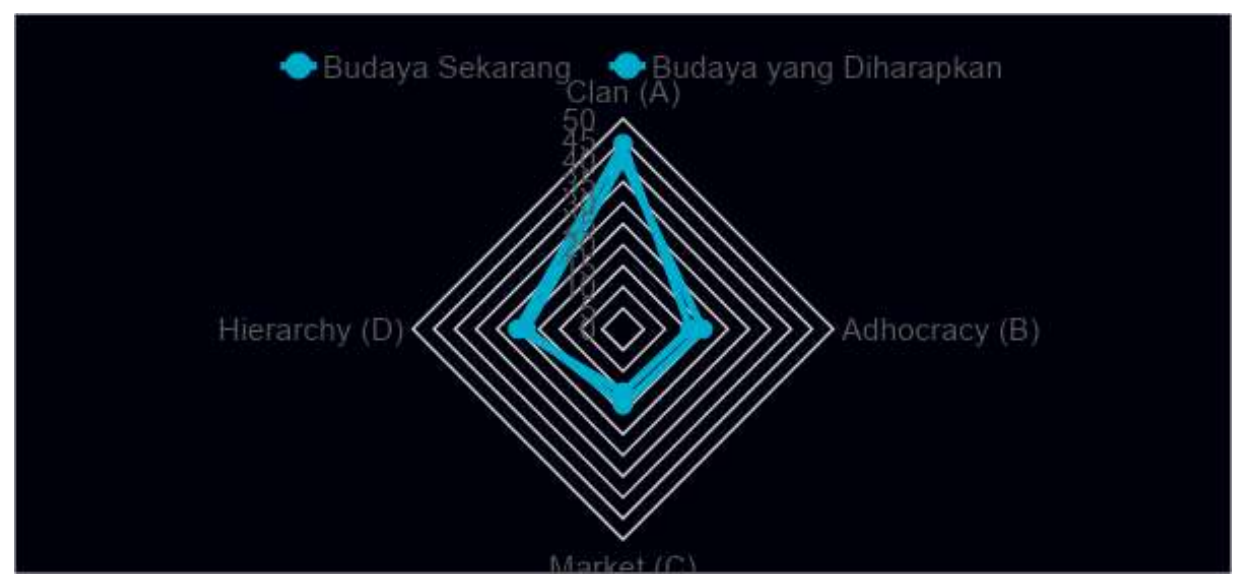

Source: Processed 2020

Figure 1. Current and Expected Leadership Culture Graph

The scores for the six dimensions can saw in the appendix. In the current market culture, there is an organizational adhesive with points that are not too high. Even though it differs significantly from the clan, it also still affects the adhesive of the organization naturally if the market has a low point because this organization is not a profit-seeking organization.

Suppose the adhocracy is the most prominent part of the leadership style. It shows that the leader who is in control of this pesantren has quite good innovation, the courage to take risks makes the leader have a very professional problem-solving.

\subsection{The Leadership's Perception of The Expected Pesantren Culture}

Describe The leadership wants pesantren culture in the future to be better than before with the results of the clan (44) and hierarchy (25). Both of these things are still the same as today's culture. However, the insignificant difference makes leaders increasingly convinced that organizational culture in pesantren needs to emphasize these two things. It can also be concluded that the leader is very compatible with the current organizational culture and 
wants to develop it again in the future. The cultural scores from highest to low were clan (44), hierarchy (25), adhocracy (16), and market (15).

Clan culture is still the culture chosen by the leadership, and this is evidence that leaders want this culture to be better than before. As a leader, it is natural to be an example in applying how to embrace other organization members so that each member feels comfortable. He can dare to be a figure loved by his subordinates even if the leader can act as a figure of an older adult who can nurture, guide, and provide the facilities desired by his subordinates.

\section{Non-Leader Assessment Results}

Perception, according to non-leadership, is dominated by clan culture (33) and hierarchy (24). It can be concluded that the non-leadership feels that the pesantren has received guidance and facilities provided by the leadership. The scores for the four cultures can be seen in the image below. The order of the highest to lowest cultural scores is clan (33), hierarchy (24), adhocracy (22), and market (21).

The cultural profile of the pesantren can be seen in the picture. The profile picture indicates that there is a slight shift from the current culture to the one expected. So this proves that the shifting line can be the possibility of developing better or decreasing. There is an increasing shift in clan culture, and there is no shift in the hierarchy.

Table 2. Non-Leadership Results Culture

\begin{tabular}{lll}
\hline Culture Type & Current Culture & Expected Culture \\
\hline CLAN & 33 & 34 \\
ADHOCRACY & 22 & 21 \\
MARKET & 21 & 21 \\
HIERARCHY & 24 & 24 \\
TOTAL & 100 & 100 \\
\hline SOurce: Processed 2020 &
\end{tabular}

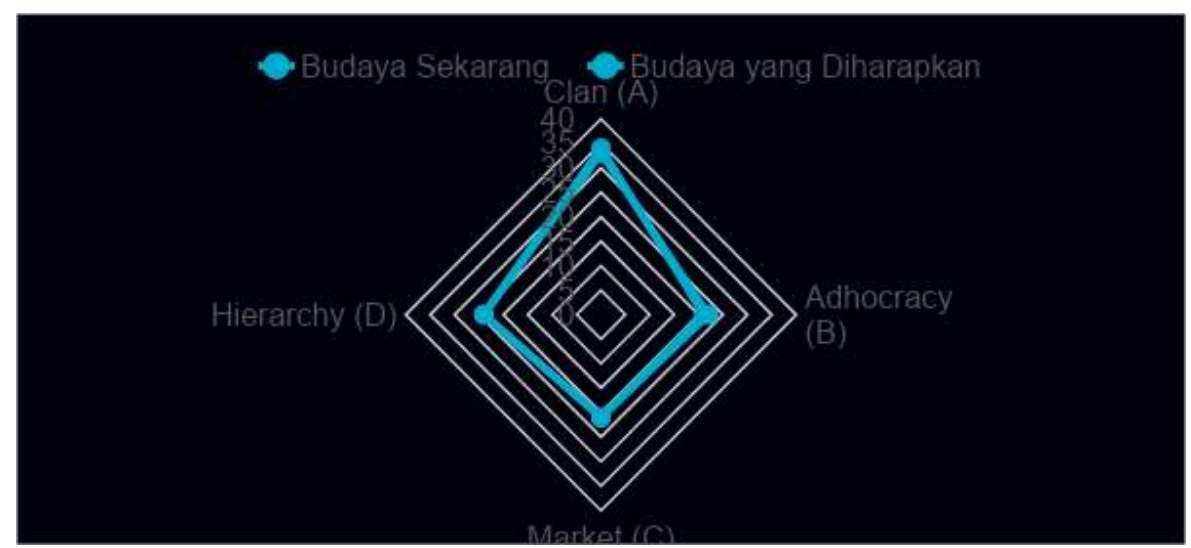

Source: Processed 2020

Figure 2. Current and Expected Non-Leadership Culture Graph 
The clan culture that is felt by non-leaders is where the figure of a leader succeeds in providing a good example and succeeds in embracing all organization members. It is the same as the results obtained from the research by the leadership above that pesantren is very different from the company, so it does not have a profit orientation.

Meanwhile, the hierarchical culture felt by non-leaders also became the glue of togetherness with the existence of rules and policies made by their leaders. Maintaining a smooth and smooth work program is very important in this organization. Many argue that success starts from being exemplary and always obeying the rules that had been setting.

\section{Non-Leadership Perceptions of The Expected Culture}

The same culture dominates the culture expected by non-leaders as the current culture. Clans and hierarchies are two cultures that were highly expecting by non-leaders to be able to develop in the organization if the order is the culture expected by non-leaders, namely clan (34), hierarchy (24), adhocracy (21), and market (21).

\section{Combined assessment results (According to the Leadership and Non-Leadership)}

Based on the combined data, it was known that the most dominant cultures are clan (35) and hierarchy (24). This result is evidence that there is a very significant difference between one culture and another. It can saw in the table below. The following is data from the highest to the lowest cultures: clan with 35 , hierarchy in the second position with 24 , adhocracy with 21 , and market with 20.

The cultural profile of the pesantren has shifted, especially in clan culture and hierarchy. Both have increased. Form clans, the number has increased quite a lot, while the hierarchy has increased by one point.

Table 3. Culture of Results of Combined Leadership and Non-Leadership[1]

\begin{tabular}{lll}
\hline Culture Type & Current Culture & Expected Culture \\
\hline CLAN & 35 & 38 \\
ADHOCRACY & 21 & 19 \\
MARKET & 20 & 18 \\
HIERARCHY & 24 & 25 \\
TOTAL & 100 & 100 \\
\hline
\end{tabular}

Source: Processed 2020 


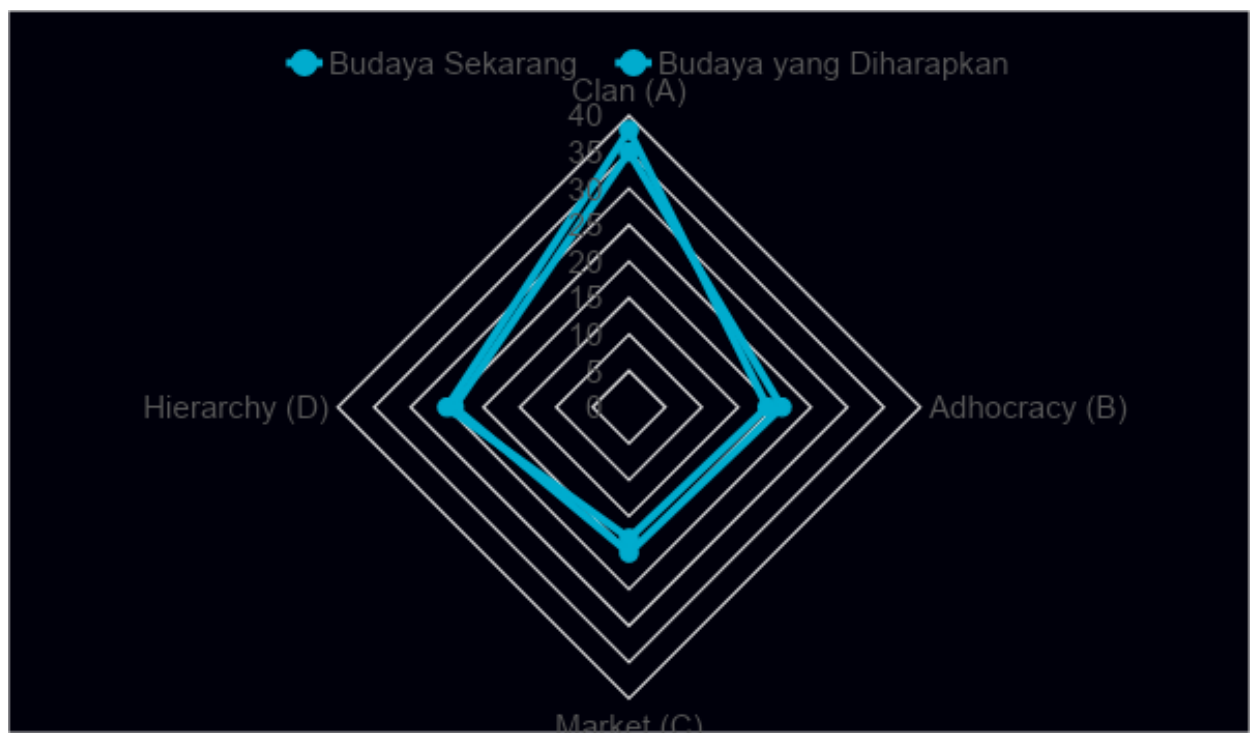

Source: Processed 2020

Figure 3. Graph of Combined Culture Between Leaders and Non Leaders

\section{The Expected Pesantren Culture}

The dominant pesantren culture expected by the leadership and non-leadership is a combination of clan culture and hierarchy. The differences between one culture and another have significant differences. What is very clear is found in clan culture. It means that the culture which had become a culture now still wants to be selected and developed for the future. After that, the hierarchical culture was following by one digit different from the current culture. It was hoping that in the future, the rules and policies of the pesantren can further be developed so that all elements in the pesantren can be tidier by having a more explicit foundation.

Overall, the results of assessing organizational culture in pesantren using the OCAI instrument can saw in the table below. Between leaders and non-leaders have similarities in the current culture and the culture that was expecting. Both want a clan culture and a hierarchical culture that is more developed for the organization's future.

Table 4. Current and Expected Dominant Culture

\begin{tabular}{|c|c|c|c|c|}
\hline Assessment & \multicolumn{2}{|c|}{ Current Type of Culture } & \multicolumn{2}{|c|}{ Expected Type of } \\
\hline Leader & CLAN (40) & HIERARCHY (23) & CLAN (44) & HIERARCHY (25) \\
\hline Non-Leader & CLAN (33) & HIERARCHY (24) & CLAN (34) & HIERARCHY (24) \\
\hline Combined & CLAN (35) & HIERARCHY (24) & CLAN (38) & HIERARCHY (25) \\
\hline
\end{tabular}

Source: Processed 2020

The results of combined research using OCAl can be seen based on the scores per dimension for each type of culture, and these scores were presented in the following table: 
Tabel 5. Results of the Recapitulation of Pesantren Culture[2]

\begin{tabular}{|c|c|c|c|c|c|c|c|c|c|c|c|c|}
\hline \multirow{2}{*}{ DIMENSION } & \multicolumn{3}{|c|}{ CLAN } & \multicolumn{3}{|c|}{ MARKET } & \multicolumn{3}{|c|}{ ADHOCRACY } & \multicolumn{3}{|c|}{ HIERARCHY } \\
\hline & $\mathrm{N}$ & $P$ & $x$ & $\mathrm{~N}$ & $P$ & $x$ & $\mathrm{~N}$ & $P$ & $x$ & $\mathrm{~N}$ & $P$ & $x$ \\
\hline $\begin{array}{l}\text { Dominant } \\
\text { Characteristics }\end{array}$ & 36 & 41 & 5 & 21 & 17 & 4 & 20 & 18 & 2 & 23 & 25 & 2 \\
\hline Leadership Style & 33 & 35 & 2 & 21 & 19 & 2 & 24 & 23 & 1 & 22 & 23 & 1 \\
\hline $\begin{array}{l}\text { Employee } \\
\text { Management }\end{array}$ & 33 & 36 & 3 & 21 & 19 & 2 & 19 & 17 & 2 & 27 & 28 & 1 \\
\hline $\begin{array}{l}\text { Organizational } \\
\text { Adhesives }\end{array}$ & 38 & 40 & 2 & 22 & 23 & 1 & 18 & 17 & 1 & 22 & 21 & 1 \\
\hline $\begin{array}{l}\text { Strategy } \\
\text { Emphasis }\end{array}$ & 34 & 38 & 4 & 20 & 20 & 0 & 21 & 20 & 1 & 25 & 23 & 2 \\
\hline $\begin{array}{l}\text { Measure of } \\
\text { Success }\end{array}$ & 36 & 38 & 2 & 20 & 19 & 1 & 20 & 20 & 0 & 24 & 23 & 1 \\
\hline
\end{tabular}

Source: Processed 2020

In the table above, the letter $\mathrm{N}$ (now) shows the culture that is currently felt, while the letter $\mathrm{P}$ (preferred) shows the expected culture in the future. In addition, column X means the difference between the current culture and the expected culture. In the previous discussion, it has been found that both leaders and non-leaders want clan culture and hierarchy, so the table above will be beneficial in applying these desires. As an example for culture and it is necessary to develop a leadership style and employee management because these two things have the most negligible value among the other values. It can be concluded that the expected culture is still loyal to the clan culture.

A culture that upholds a sense of kinship makes the performance of the organization run smoothly. A leader who can be an example and can protect each individual is vital in this culture. According to Syukri et al., in 2019, it is proven that the leadership style will significantly affect members' performance in the organization. Apart from a sense of kinship, supporting facilities also really need to be prepared by the leadership ranks. According to Yuliana, in 2017 , providing suitable facilities will significantly affect the satisfaction and comfort of workers and consumers.

Meanwhile, previous research has also strengthened the hierarchical culture that emphasizes procedures and regulations to serve as the glve of an organization. According to Kristian and Ria in 2019, the results of their research explain a positive influence resulting from research on work motivation and discipline towards employees. It reinforces that the steps that need to be taken by this organization are to develop work discipline further and provide motivation to organizational members. The magnitude of leadership style, office facilities, and work discipline on employee performance is $64.4 \%$ (Irawan and Nanik, 2018). 


\section{CONCLUSION}

Based on the research results related to the Identification of Organizational Culture at the Imam Syuhodo Sukoharjo Modern Islamic Boarding School, it can be concluded that clan culture is the main character of the organization at the Imam Syuhodo Sukoharjo Islamic Boarding School. Whereas the unique character is that almost all business charity actors are cadres from Muhammadiyah, the current organizational culture is dominated by clans with a score of 35 while the hierarchy with a score of 24 . In the future, the expected culture is a clan with a score of 38 , which means that it develops 3 points hierarchy with a score of 25 , which means 1 point develops, the unique character possessed by the Imam Syuhodo Islamic Boarding School that distinguishes it from other Islamic boarding schools is the learning system, for junior high school level under the department of religion while for high school level under the department of education.

\section{REFERENCES}

Adi, B. W. 2013. Analisis Pengaruh Budaya Organisasi, Kepemimpinan dan Motivasi Kerja Terhadap Komitmen Organisasi dan Implikasinya pada Kinerja Kepala Sekolah. Jurnal Pendidikan dan Kebudayaan, 19 (2), 206-221.

Allison, J. 2018. Values Statement The Missing Link Between Organizational Culture, Strategic Management, and Strategic Communication. International Journal of Organizational Analysis, 27 (3). DOI: https://doi.org/10.1108/IJOA-08-2018-1501

Amia, L., Agus W., \& Rosidah S. 2013. Kajian Budaya Organisasi Bina Nusantara University Menuju "A World Class University". Humaniora, 4 (2), 1247-1259. DOI: https://doi.org/10.21512/humaniora.v4i2.3568

Carl, R. Steinhoff R. G., \& Owens. 1989. The Organizational Culture Assessment Inventory: A Metaphorical Analysis in Educational Settings. Journal of Educational Administration, 27 (3). DOI: http://dx.doi.org/10.1108/EUM0000000002463

Cameron, K. S., \& Quinn, R. E. 2006. Diagnosing and Changing Organizational Culture: Based on the Competing Values Framework, Revised Ed. USA: Jossey-Bass Publisher.

Dion, M. 1996. Organizational Culture as Matrix of Corporate Ethics. The International Journal of Organizational Analysis, 4 (4), 329-351. DOI: http://dx.doi.org/10.1108/eb028855

Edison, E., Yohny A., \& Imas K. 2017. Manajemen Sumber Daya Manusia. Bandung: ALFABETA.

Fahmi, A. H., \& Neni H. 2019. The Practice of local economic development and Maqasid alShari'ah. International Journal of Islamic and Middle Eastern Finance and Management,12 (5), 625-642. DOI: https://doi.org/10.1108/IMEFM-08-2018-0279

Harrison, T., \& Dianna L. S. 2018. Effects of Organizational Values and Employee Contact OneRecruiting. Journal of Managerial Psychology. DOI: https://doi.org/10.1108/JMP-03-2017$\underline{0118}$ 
Irawan, A., \& Nanik S. 2018. Pengaruh gaya Kepemimpinan, Fasilitas Kantor dan Disiplin Kerja Terhadap Kinerja Pegawai Dinas Perdagangan Kota Semarang. Economic Education $\begin{array}{llll}\text { Analysis Journal, } & 7 & \text { (1), 265-278. }\end{array}$ https://journal.unnes.ac.id/sju/index.php/eeaj/article/view/22876

Kristanti, D., \& Ria L. 2019. Pengaruh Disiplin Kerja Karyawan dan Motivasi Terhadap Kinerja Karyawan Bagian Produksi. Jurnal Nusamba, 4 (2), 107-116. DOI: https://doi.org/10.29407/nusamba.v4i2.13808

Melanie, C. B., Jeffrey S. B., Agus M., \& Imam T. 2020. Principals as Socio-religious curators: progressive and conservative approaches in Islamic schools. Journal of Educational Administration. DOI: https://doi.org/10.1108/JEA-01-2020-0004

Moeheriono, E. 2012. Pengukuran Kinerja Berbasis Kompetensi. Jakarta: Raja Grafindo Persada.

Mukhibat, M. 2015. Meneguhkan Kembali Budaya Pesantren Dalam Merajut Lokalitas, Nasionalitas, dan Globalitas. Karsa: Jurnal Sosial dan Budaya Keislaman, 23 (2), 1-16. ISSN 2442-4285.

Nelfianti, F., Yuniasih, I., \& Wibowo, A. I. 2018. Pengaruh Budaya Organisasi Terhadap Kinerja Karyawan YPI Cempaka Putih Jakarta. Jurnal Kajian IImiah, 18 (2), 120-128.

Music, I. S. M. H. 2016. Organizational Culture of the Croatian Construction Industry. Engineering, Construction and Architectural Management, 23 (2). DOI: http://dx.doi.org/10.1 108/ECAM-02-2015-0019

Pedro E. P., \& Mateus C. G. 2017. Organizational Culture for Learn Programs. Journal of Organizational Change Management, 30 (4). DOI: http://dx.doi.org/10.1 108/JOCM-022016-0039

Robbins, S. P., \& Timothy A. J. 2015. Perilaku Organisasi, Edisi ke-16. Terjemahan oleh Ratna Saraswati Jakarta: Salemba Empat.

Supariyanto, S. 2014. Penerapan Budaya Organisasi Pada PT. PLN (Persero) Rayon Bangkinang. Jom FISIP, 1 (2), 1-15.

Susilo, J. 2018. Penggunaan OCAl (Oragnizational Culture Assessment Instrument) untuk Analisa Budaya Organisasi di PPSDM Migas. Swara Patra, 8 (4), 1-18. http://ejurnal.ppsdmmigas.esdm.go.id/sp/index.php/swarapatra/article/view/7

Syukri, M., Surasni, N. K., \& Furkan, L. M. 2019. Pengaruh Partisipasi Anggaran dan Gaya Kepemimpinan Terhadap Kinerja Manajerial dengan Job Relevant Information sebagai Pemoderasi. E-Jurnal Akuntansi, 29 (3), 987-996.

Usman, K. 2019. Impact of Organizational Culture, Organizational Communication and Supervisor Support on The Job Satisfaction of Employees Working in Online IT-Based Distance Learning Institutions of Pakistan. Open Praxis Journal, 11, 143-156. DOI: https://search.informit.org/doi/10.3316/informit.463519497835570 
Wartini, S. 2014. Analisis Kinerja Organisasi Melalui Kepemimpinan Transformasional dan Budaya Organisasi. Jurnal Akuntansi dan Pendidikan, 3 (1), 1-12. DOI: http://doi.org/10.25273/jap.v3i1.1206

Yuliana, D. 2017. Pengaruh Fasilitas, Layanan dan Informasi Aksebilitas Terhadap Tingkat Kepuasan Penumpang di Bandara Husein Sastranegara Bandung. Warta Ardhia 43 (1), 27-42. DOI: $\mathrm{http://dx.doi.org/10.25104/wa.v43i1.235.27-42}$

Zuhriy, M. S. 2011. Budaya pesantren dan pendidikan karakter pada pondok pesantren salaf. Walisongo: Jurnal Penelitian Sosial Keagamaan, 19 (2), 287-310. DOI: https://doi.org/10.21580/ws.19.2.159 